Nordic Concrete Research - Publ. No. NCR 60 - ISSUE 1 / 2019 - Article 1, pp. 1-12

\begin{tabular}{|c|c|}
\hline S sciendo & 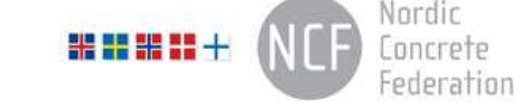 \\
\hline \multirow{2}{*}{$\begin{array}{l}\text { (C) Article authors. This is an open access article distributed under } \\
\text { the Creative Commons Attribution-NonCommercial-NoDerivs } \\
\text { licens. (http://creaticecommons.org/licenses/by.nc-nd/3.0/). }\end{array}$} & ISSN online $2545-2819$ \\
\hline & ISSN print $\quad 0800-6377$ \\
\hline \multirow{3}{*}{ DOI: $10.2478 /$ ncr-2019-0004 } & Received: March 26, 2019 \\
\hline & Revision received: June 19, 2019 \\
\hline & Accepted: June 25, 2019 \\
\hline
\end{tabular}

\title{
Case Study on the 20 Years Propagation of Carbonation in Existing Concrete Facades and Balconies
}

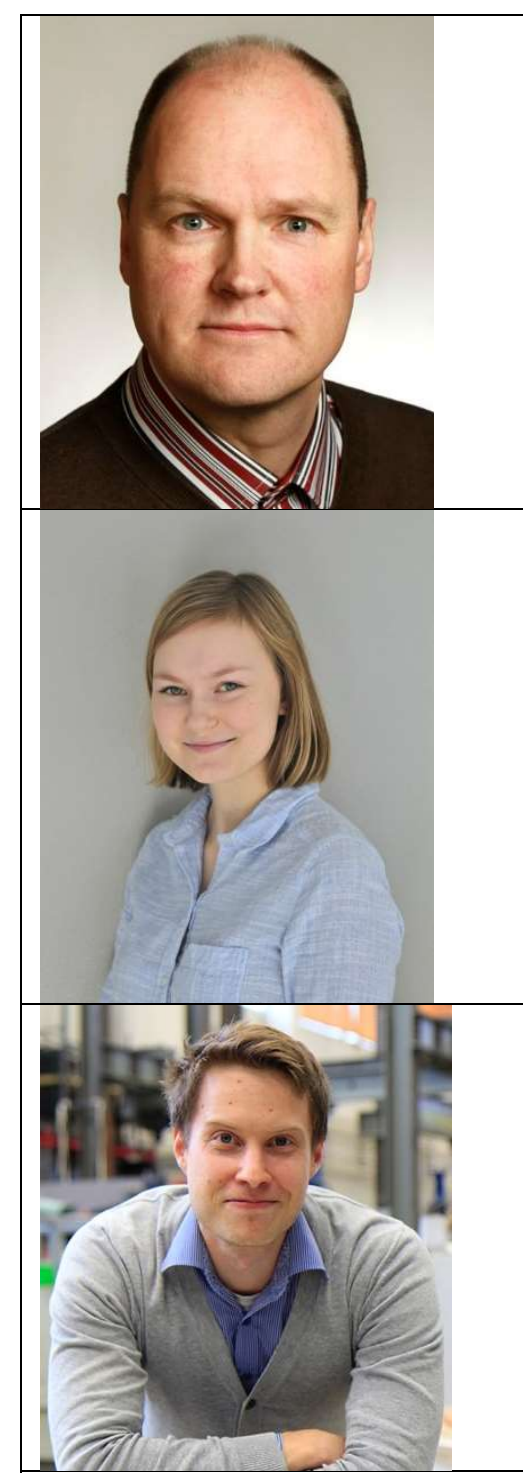

Jukka Lahdensivu, DSc.

Adjunct Professor at Tampere University

Faculty of Built Environment

Korkeakoulunkatu 10

FI-33720 Tampere, Finland

jukka.lahdensivu@tuni.fi

Elina Lahdensivu

MSc Student at Tampere University

Faculty of Built Environment

Korkeakoulunkatu 10,

FI-33720 Tampere, Finland

elina.lahdensivu@tuni.fi

Arto Köliö, DSc.

Postdoctoral researcher, Tampere University

Faculty of Built Environment

Korkeakoulunkatu 10

FI-33720 Tampere, Finland

arto.kolio@tuni.fi 


\begin{abstract}
In the most service life models of reinforced concrete structures the initiation phase is the most crucial, because according to models, service life of the structure will end underestimation on conservative side when carbonation achieves the reinforcement for the first time. The square root model is widely used in predicting carbonation depth of reinforced concrete. The model is based on diffusion laws and thereby arguable for inhomogeneous concrete. The model was evaluated by field measurements from one existing concrete building by conducting condition investigation twice at a time interval of 20 years. Samples were taken from exposed aggregate concrete sandwich panels and balcony side panels. Compared to the data collected from large number of buildings, the measured carbonation rates were very common for Finnish concrete buildings made during the 1960s and 1970s. According to this study, in solid concrete the progress of carbonation of concrete can be predicted reliably with Fick's second law. This model, however, gives too pessimistic predictions for concrete suffering from freeze-thaw damage. Therefore, a new model has been presented for damaged concrete.
\end{abstract}

Key words: Concrete, carbonation, corrosion, field measurement, service life, modelling

1.

\title{
INTRODUCTION
}

1.1

General

Carbonation induced corrosion of reinforcement together with freeze-thaw damage in concrete facades and balconies are the major degradation mechanisms causing repair need in Finland [1]. Corrosion of steel reinforcement in concrete is commonly regarded as an electrochemical phenomenon meaning that corroding reinforcement works as a mixed electrode where cathodic and anodic areas are formed on the steel surface [2]. The size of anodes and cathodes determine the nature of corrosion. Corrosion due to carbonation is general over the reinforcement surface with relatively evenly spaced cathode and anode areas. [3]. Because concrete protects steel from corrosion as a protective layer for the reinforcement, corrosion does not initiate immediately. This has been taken into account by depicting reinforcement corrosion as a process consisting of two or more consecutive phases $[4,5,6]$ as shown in Figure 1.

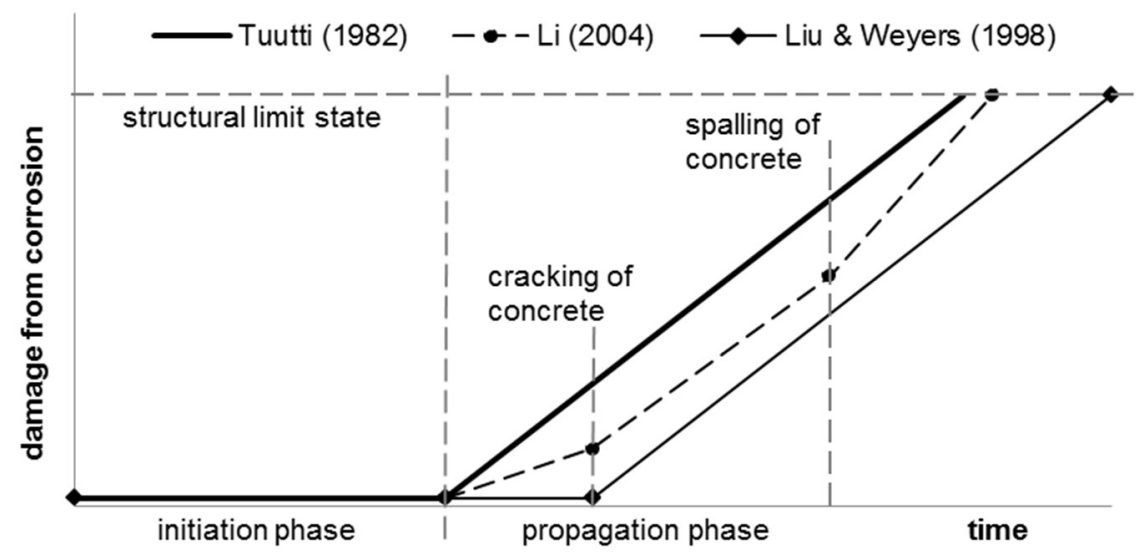

Figure 1 - Models for reinforcement corrosion utilizing the principle of initiation and propagation. 
According to Finnish concrete codes [7,8] the service life of reinforced concrete structure will end when carbonation of concrete achieves the steel bar first time. To determine the service life of the reinforced concrete structure it is important that the calculation of the initiation phase is correct.

This study analyses the actual observed progress of carbonation on concrete facades and balconies in one actual building situated in Helsinki suburban area by a survey of condition assessments made in 1994 [9] and repeated sampling in 2014 enabling a 20 years' time interval. This information is contrasted to the widely used square root model to evaluate its use in predicting the progression of carbonation in concrete structures exposed to Nordic climate.

\section{Case study in Jakomäki}

Jakomäki suburban area is situated in northern Helsinki, approximately $16 \mathrm{~km}$ northeast from the city centre. The area consists of 31 blocks of flats, which are built between 1967 and 1969. In general, those blocks of flats have 3 to 6 floors. About 5800 inhabitants live in the area. Tampere University of Technology (TUT) carried out large condition investigation program to the concrete facades and balconies of Jakomäki buildings in 1994. Several degradation mechanisms were found on concrete facades and balconies after 25 years' service life. Based on the condition assessment a large renovation program was launched in 1996 and it ended in 2014 to the demolition of two last buildings, while others were renovated.

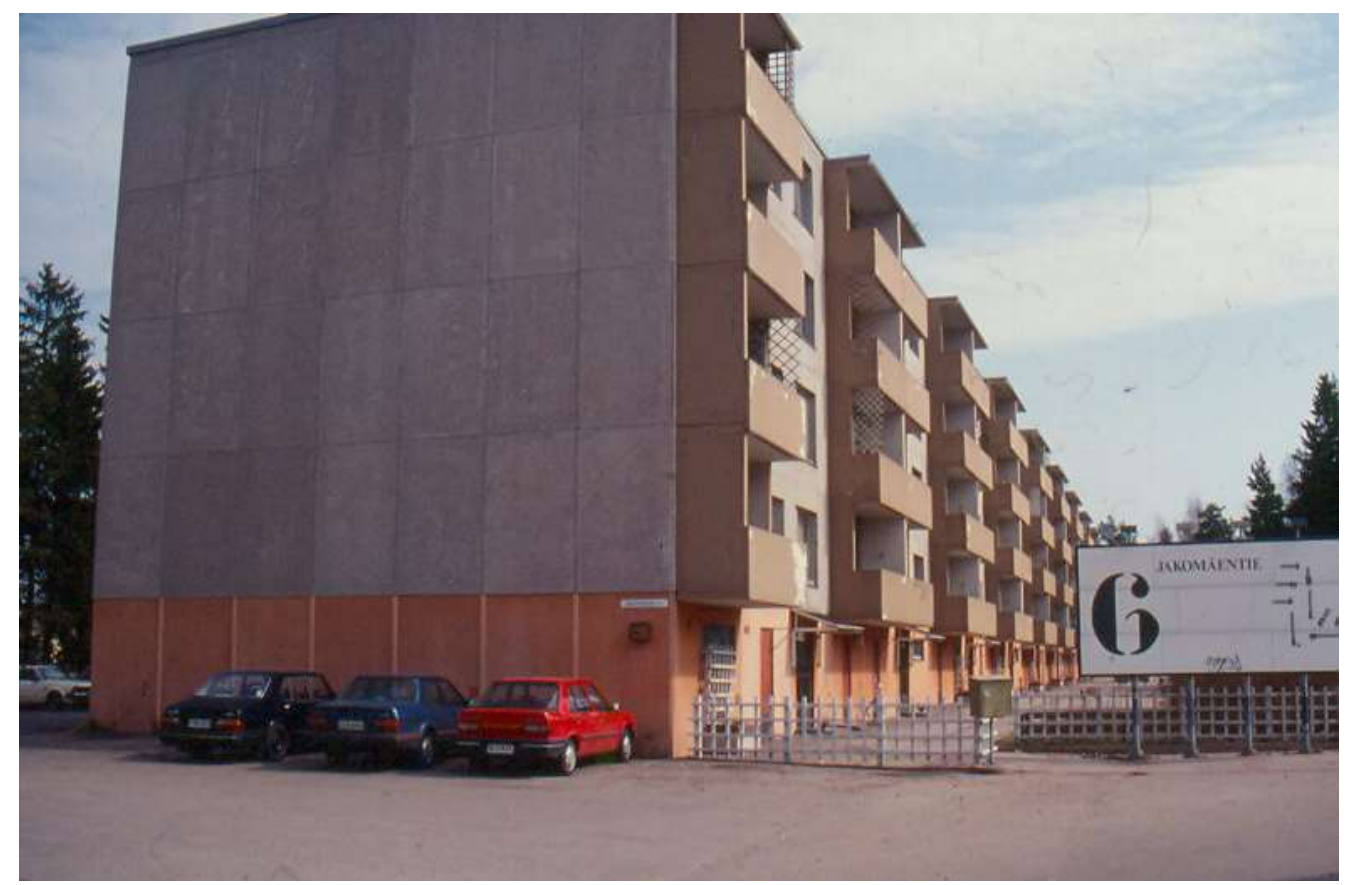

Figure 2 - Case building in 1994 during first condition investigation.

The case study building was completed in 1968. It was a 5-storey block of flats with exposed aggregate concrete facades and suspended concrete balconies, see Figure 2. The structure of this building consist of prefabricated sandwich facade panels and balcony slab, frame and parapet elements. The surface of facades was exposed aggregate concrete and balconies were painted with non-permeable paint. The typical dimensions of precast panels of the case study building are shown in Table 1 based on the first condition assessment. The case study building was demolished 
in the end of 2014 after being in service for 46 years. Before demolition several samples were taken from facades and balcony frames.

Table 1 -Dimensions and reinforcement properties of prefabricated facades and balconies in the case study building.

\begin{tabular}{|c|c|c|c|}
\hline $\begin{array}{c}\text { Structure/ } \\
\text { unit }\end{array}$ & Dimensions & Reinforcement & Comments \\
\hline $\begin{array}{c}\text { Facade } \\
\text { sandwich } \\
\text { panel }\end{array}$ & $\begin{array}{l}\text { Outer layer } 61-82 \\
\text { mm, } \\
\text { Inner layer } 80 \mathrm{~mm} \\
\text { (non-bearing) or } \\
150 \mathrm{~mm} \text { (load } \\
\text { bearing) }\end{array}$ & $\begin{array}{c}\text { Outer layer: } \\
\text { mesh } 3 \mathrm{~mm} \text { with } 150 \mathrm{~mm} \\
\text { spacing, } \\
\text { edge rebars } 6 \text { and } 8 \mathrm{~mm} \text {, } \\
\text { trusses connecting outer and } \\
\text { Inner layer spacing } 600 \mathrm{~mm} \text {, } \\
\text { aux. reinforcement/lifting } \\
\text { straps }\end{array}$ & $\begin{array}{l}\text { Thickness of thermal } \\
\text { insulation } 78-99 \mathrm{~mm} \text {, } \\
\text { elastic element joints } \\
\text { (polymer sealants), } \\
\text { no ventilation gap = } \\
\text { dries slowly }\end{array}$ \\
\hline $\begin{array}{c}\text { Balcony } \\
\text { slab }\end{array}$ & $\begin{array}{l}\text { thickness 130-160 } \\
\text { mm (sloped upper } \\
\text { surface) }\end{array}$ & $\begin{array}{l}\text { Bearing reinforcement: } \\
10 \mathrm{~mm} \text { spacing } 100-150 \mathrm{~mm} \\
\text { in the lower section of the slab } \\
\text { upper section: tie rods, aux. } \\
\text { reinforcement, lifting straps }\end{array}$ & $\begin{array}{l}\text { Water drainage } \\
\text { system: spout pipe } \\
\text { through the parapet. } \\
\text { No waterproofing. }\end{array}$ \\
\hline $\begin{array}{l}\text { Balcony } \\
\text { side panel }\end{array}$ & $\begin{array}{c}\text { Thickness 162-166 } \\
\mathrm{mm}\end{array}$ & $\begin{array}{l}8 \mathrm{~mm} \text { mesh in both surfaces } \\
\text { with } 200 \mathrm{~mm} \text { spacing } \\
\text { edge rebars } 10 \mathrm{~mm}, \\
\text { aux. reinforcement/lifting } \\
\text { straps }\end{array}$ & $\begin{array}{l}\text { The bottom side } \\
\text { panel is suspended } \\
\text { from the head of } \\
\text { partition wall with six } \\
18 \mathrm{~mm} \text { rebars. }\end{array}$ \\
\hline $\begin{array}{l}\text { Balcony } \\
\text { parapet }\end{array}$ & $\begin{array}{c}\text { Thickness } 95-98 \\
\text { mm }\end{array}$ & $\begin{array}{l}\text { Heavy reinforcement near } \\
\text { both surfaces, rebars } 6 \mathrm{~mm} \\
\text { spacing } 150 \mathrm{~mm}\end{array}$ & $\begin{array}{l}\text { Connected to side } \\
\text { panel with steel } \\
\text { plates and bolts. }\end{array}$ \\
\hline
\end{tabular}

\section{2.}

\section{CARBONATION OF CONCRETE}

Carbonation of concrete is a chemical reaction between alkaline hydrates of concrete and carbon dioxide gas both dissolved in concrete pore water. The reaction product is calcium carbonate, which lowers the $\mathrm{pH}$ of the pore water (and concrete) gradually to a level where steel can corrode. As the alkaline hydroxide reservoir in concrete is limited, it is eventually completely consumed leading to the neutralization of concrete. Since carbon dioxide originates from the atmosphere the concrete structure is exposed to, carbonation advances inside concrete as a carbonation front and the diffusion of it inside concrete serves as a limiting factor for its progression. [10].

Factors that limit carbonation are (1) moisture content of concrete, (2) reserve of calcium hydroxide in cement, (3) impermeability of concrete, (4) low $\mathrm{CO}_{2}$ concentrations in air and (5) outwards diffusion of $\mathrm{OH}^{-}$in water saturated concrete [5]. These factors are related to e.g. the thickness of concrete cover, high cement content and pore structure as well as the water-cement ratio of the concrete as actual properties of the structure $[10,11]$ and the amount of atmospheric $\mathrm{CO}_{2}$ and precipitation (sources of moisture) as external environment properties. 
Because carbonation is controlled by the diffusion of carbon dioxide inside concrete, it is commonly modelled with a square root relationship with time, see Eq. 1, [5] derived from the differential equation of diffusion [9]. The rate of carbonation, including the effect of both internal and external factors, is in this model denoted by the factor $k$ (carbonation coefficient).

$x=k \cdot \sqrt{t}$

where,

$x=$ carbonation depth

$k=$ carbonation coefficient $\left[\mathrm{mm} \cdot \mathrm{a}^{-1 / 2}\right]$

$t=$ time $[\mathrm{a}]$.

Extensive research has been conducted since late 1950s on relating carbonation depth in laboratory environment to such concrete properties as water-cement ratio, compressive strength and curing as well as controlled levels of carbon dioxide or relative humidity [11].

Many models have been proposed for depicting carbonation all utilizing the square root relationship [10]. Although, it is mentioned that empirical measurements indicate that, especially in the cases of concrete exposed to rain, the exponent for time is less than $0.5[5,12]$. Therefore, the square root equation should be regarded as an upper limit for carbonation in these cases. The square root equation has also been developed to separate the influence of different individual internal and external factors to carbonation [13] and further on to isolate the influence of specific factors [14] opposed to the one parameter in Eq. 1.

\section{CONDITION INVESTIGATIONS MADE FOR THE BUILDING}

\subsection{Condition investigation}

In Finland concrete facades have been subjected to condition assessments since late 1980s and data measured by standardised procedures [15] have been produced in majority of these assessments. The condition assessments consist of preliminary desk top studies, visual observation and rating in situ, measurements and sampling in situ and laboratory tests [16].

Carbonation depth has been measured from core samples taken during the field investigation by spraying freshly cut surface with a phenolphthalein $\mathrm{pH}$ indicator. The carbonation depth is measured from a single sample as the average and the maximum depth of the carbonation front. By average 12 samples have been taken from one building during a single condition assessment in general [16].

\subsection{First condition investigation}

First condition assessment was carried out to the case study building during the summer 1994. Totally 44 concrete samples were taken from facades and balconies. According to original construction plans concrete grade was $\mathrm{C} 25 / 30$ both in facades and balconies.

Concrete samples with the diameter of $50 \mathrm{~mm}$ were extracted from the outer concrete layer of the façade and from balcony panels by a diamond core drill. The samples were marked on site and 
stored for further studies and analyses. All of the samples were subjected to a thorough visual inspection for the concrete quality (e.g. pores, capillaries, and any damage visible to the naked eye). Also the carbonation depth was recorded during the visual inspection.

Part of the samples were then prepared for the microscopic study from a thin section and part of the samples were tested for the pore structure (capillary porosity and protective porosity) by the standard SFS 4475 and tensile strength by the standard SFS 5445. In standard SFS 4475 the weight of concrete samples is measured as oven dry $\left(+105 \pm 2{ }^{\circ} \mathrm{C}\right)$, capillary saturated and pressure saturated (all pores forced to saturate high pressure). Protective pore ratio $p_{r}$ is calculated as follows:

$p_{r}=\left(p_{p}-p_{c}\right) /\left(p_{c}-p_{d}\right)$

where,

$p_{r}=$ protective pore ratio [-]

$p_{p}=$ weight of the totally saturated sample $[\mathrm{g}]$

$p_{c}=$ weight of the capillary saturated sample $[\mathrm{g}]$

$p_{d}=$ weight of the oven dry sample $[\mathrm{g}]$.

All of the analyses carried out with the samples aimed at determining the quality, durability properties and evident degradation in the façade concrete.

\section{3}

\section{Sampling 2014}

After the initial condition investigation in 1994, a decision was made concerning the case study building that no repairs were carried out. Instead the case study building, and its neighbouring building were meant to serve as long as possible and then be demolished. Before the demolishing of the building in the late autumn 2014, a repeated sampling was carried out.

Core samples were extracted from the outer concrete layer of the façade and from balcony frame panels in the same way as in the first condition investigation. The sampling was focused on the south-eastern façade to enable the collection of as many samples as possible in limited time. 14 samples with the diameter of $75 \mathrm{~mm}$ and three samples with the diameter of $100 \mathrm{~mm}$ were taken from the exposed aggregate facades and four samples with the diameter of $75 \mathrm{~mm}$ were taken from the balcony panels. The samples were inspected visually in the same way, but by a different person than in the first time. The inspection is standardized so that error caused by different assessor should be minimised. The carbonation depth was recorded during the visual inspection from all samples.

The samples were then tested for the pore structure (capillary porosity and protective porosity) by the standard SFS 4475. The larger samples (diameter of $100 \mathrm{~mm}$ ) were subjected to compressive strength tests.

Before demolishing the building, sampling was carried out during late autumn 2014. Totally 21 samples were drilled from balcony frames and facades. 


\section{RESULTS AND DISCUSSION}

\subsection{Carbonation of concrete}

Carbonation of concrete was measured with phenolphthalein $\mathrm{pH}$ indicator on the surface of drilled sample. All measurements are shown in Table 2.

In 1994 condition investigation carbonation of concrete was $12 \mathrm{~mm}$ in average with $3.8 \mathrm{~mm}$ standard deviation in exposed aggregate concrete facades. This mean $2.28 \mathrm{mma}^{-1 / 2}$ average carbonation coefficient. Only some single corrosion damage was seen. $13 \%$ of measured cover depths were less than $5 \mathrm{~mm}$. On the other hand, exposed aggregate concrete facades were found non-freeze-thaw resistant and some incipient freeze-thaw damage was detected in thin-section analyses. The cracking caused by the freeze-thaw damage may also slightly have increased the carbonation rate of the façade concrete. For this reason, also the freeze-thaw resistance and damage are briefly discussed in next chapter.

Table 2 -Carbonation depth of concrete and carbonation coefficient of all samples measured in 1994 and 2014.

\begin{tabular}{|c|c|c|c|c|c|}
\hline \multirow{2}{*}{$\begin{array}{c}1994 \\
\text { Sample } \\
\text { number }\end{array}$} & \multicolumn{5}{|c|}{2014} \\
\hline & $\begin{array}{c}\text { Carbonation } \\
\text { depth av. } \\
{[\mathrm{mm}]}\end{array}$ & $\begin{array}{c}\text { Carbonation } \\
\text { coefficient, } k \\
{\left[\mathrm{~mm} / \mathrm{a}^{0.5}\right]}\end{array}$ & $\begin{array}{l}\text { Sample } \\
\text { number }\end{array}$ & $\begin{array}{c}\text { Carbonation } \\
\text { depth av. } \\
{[\mathrm{mm}]}\end{array}$ & $\begin{array}{c}\text { Carbonation } \\
\text { coefficient, } k \\
{\left[\mathrm{~mm} / \mathrm{a}^{0.5}\right]}\end{array}$ \\
\hline $6 \mathrm{a} 2 \mathrm{sw}$ & 4 & 0,78 & $\mathrm{~J} 1 \mathrm{sW}$ & 12 & 1.77 \\
\hline $6 \mathrm{a} 5 \mathrm{sw}$ & 17 & 3.33 & $\mathrm{~J} 2 \mathrm{sw}$ & 10 & 1.47 \\
\hline $6 \mathrm{a} 7 \mathrm{sw}$ & 20 & 3.92 & $\mathrm{~J} 3 \mathrm{sw}$ & 8 & 1.18 \\
\hline $6 \mathrm{a} 8 \mathrm{sw}$ & 16 & 3.14 & $\mathrm{~J} 4 \mathrm{sw}$ & 11 & 1.62 \\
\hline $6 \mathrm{a} 9 \mathrm{sw}$ & 6 & 1.18 & $\mathrm{~J} 5 \mathrm{sw}$ & 11 & 1.62 \\
\hline $6 a 14$ sw & 10 & 1.96 & J6 sw & 13 & 1.92 \\
\hline $6 a 15 \mathrm{sw}$ & 9 & 1.77 & J7 sw & 14 & 2.06 \\
\hline $6 a 16 \mathrm{sw}$ & 11 & 2.16 & J8 sw & 11 & 1.62 \\
\hline $6 a 17$ sw & 12 & 2.35 & J9 sw & 12 & 1.77 \\
\hline $6 a 19 \mathrm{sw}$ & 5 & 0.98 & $\mathrm{~J} 10 \mathrm{sw}$ & 11 & 1.62 \\
\hline $6 \mathrm{a} 20 \mathrm{sw}$ & 14 & 2.75 & $\mathrm{~J} 11 \mathrm{sw}$ & 8 & 1.18 \\
\hline $6 a 21 \mathrm{sw}$ & 8 & 1.57 & $\mathrm{~J} 12 \mathrm{sw}$ & 9 & 1.33 \\
\hline $6 a 22 \mathrm{sw}$ & 10 & 1.96 & $\mathrm{~J} 13 \mathrm{sw}$ & 10 & 1.47 \\
\hline $6 a 23 \mathrm{sw}$ & 12 & 2.35 & $\mathrm{~J} 14 \mathrm{sw}$ & 9 & 1.33 \\
\hline $6 \mathrm{a} 26 \mathrm{sw}$ & 11 & 2.16 & $\mathrm{~J} 15 \mathrm{sw}$ & 11 & 1.62 \\
\hline $6 a 35 \mathrm{sw}$ & 9 & 1.77 & $\mathrm{~J} 16 \mathrm{sw}$ & 12 & 1.77 \\
\hline $6 a 36 \mathrm{sw}$ & 14 & 2.75 & J17 sw & 11 & 1.62 \\
\hline $6 \mathrm{a} 37 \mathrm{sw}$ & 16 & 3.14 & average & 10.8 & 1.59 \\
\hline $6 a 38 \mathrm{sw}$ & 13 & 2.55 & & & \\
\hline $6 a 39 \mathrm{sw}$ & 12 & 2.35 & PP2 sp & 22 & 3.24 \\
\hline $6 a 41 \mathrm{sw}$ & 6 & 1.18 & PP3 sp & 26 & 3.83 \\
\hline $6 a 44$ sw & 15 & 2.94 & PP4 sp & 19 & 2.80 \\
\hline average & 12,0 & 2,28 & PP5 sp & 15 & 2.21 \\
\hline & & & average & 20.5 & 3.02 \\
\hline $6 \mathrm{a} 27 \mathrm{sp}$ & 17 & 3.33 & & & \\
\hline $6 \mathrm{a} 28 \mathrm{sp}$ & 13 & 2.55 & & & \\
\hline average & 15.0 & 2.94 & & & \\
\hline
\end{tabular}

$\mathrm{sW}=$ Exposed aggregate concrete sandwich panel 
$\mathrm{sp}=$ Balcony side panel

In balcony frames carbonation of concrete was $15 \mathrm{~mm}$ in average (only two samples), which mean $2.94 \mathrm{mma}^{-1 / 2}$ average carbonation coefficient. Cover depths were too small in general, $70 \%$ of reinforcement was in the depth of $15 \mathrm{~mm}$ or less. There were several visually seen corrosion damages in balcony frames.

In 2014 average carbonation in balcony frames was $21 \mathrm{~mm}$ with $4.0 \mathrm{~mm}$ standard deviation. In facades average carbonation depth was $11 \mathrm{~mm}$ with $1.6 \mathrm{~mm}$ standard deviation.

\subsection{Freeze-thaw resistance and capillary porosity of concrete}

Façade panels were not freeze-thaw resistant in the first place. Protective pore ratio was approximately 0.05 (std. dev. 0.02). According to Finnish national concrete guideline in force during construction of this building, the protective pore ratio should be 0.20 at least for freezethaw resistant concrete [16]. Serious and wide spread freeze-thaw damage was detected in thinsection analyses during the first condition investigation. Capillary porosity of concrete was 6.5 vol-\% (std. dev. 0.9), which is the most typical value for exposed aggregate concrete made in 1960s and 1970s [1].

From balcony structures, only two samples were taken. Protective pore ratio was 0.12 and 0.14 , which is the most common value for balconies in that era. Concrete was not freeze-thaw resistant in balconies either, but no damage was detected.

\subsection{Progress of carbonation during last 20 years}

The first condition investigation was carried out in 1994 with 38 samples in total from different kinds of concrete panels and from all the facades, but only 7 of them were comparable to the second investigations samples. The second investigation took place in 2014 with 21 samples but only from south-eastern facade. Results can be seen in table 3 .

Table 3 - Average and standard deviation of measured carbonation coefficient.

\begin{tabular}{ccccccc}
\hline & $\begin{array}{c}1994 \\
\text { Outer } \\
\text { surface av. } \\
{[\mathrm{mm}]}\end{array}$ & $\begin{array}{c}\text { Carbonation } \\
\text { coefficient, } \\
k\left[\mathrm{~mm} / \mathrm{a}^{0.5}\right]\end{array}$ & $\begin{array}{c}\text { Standard } \\
\text { deviation }\end{array}$ & $\begin{array}{c}2014 \\
\text { Outer } \\
\text { surface av. } \\
{[\mathrm{mm}]}\end{array}$ & $\begin{array}{c}\text { Carbonation } \\
\text { coefficient, } \\
k\left[\mathrm{~mm} / \mathrm{a}^{0.5}\right]\end{array}$ & $\begin{array}{c}\text { Standard } \\
\text { deviation }\end{array}$ \\
\hline $\begin{array}{c}\text { Sandwich } \\
\text { panels to }\end{array}$ & $10(\mathrm{n}=5)$ & 2.04 & 0.53 & $11(\mathrm{n}=17)$ & 1.59 & 0.24 \\
$\begin{array}{c}\text { South-East } \\
\text { Balcony } \\
\text { side panels } \\
\text { to South- } \\
\text { East }\end{array}$ & $15(\mathrm{n}=2)$ & 2.94 & - & $21(\mathrm{n}=4)$ & 3.02 & 0.69 \\
\hline
\end{tabular}

On the balcony side panels, the carbonation coefficient is approximately the same in both investigations. The standard deviation is also approximately the same, and carbonation curve follows Eq. (1) nicely, see Figure 3. On the other hand, in sandwich panels, the carbonation 
coefficient is very different between 1994 and 2014. Results from 2014 investigation do not follow the equation based on the first condition investigation, see blue dots in Figure 3.

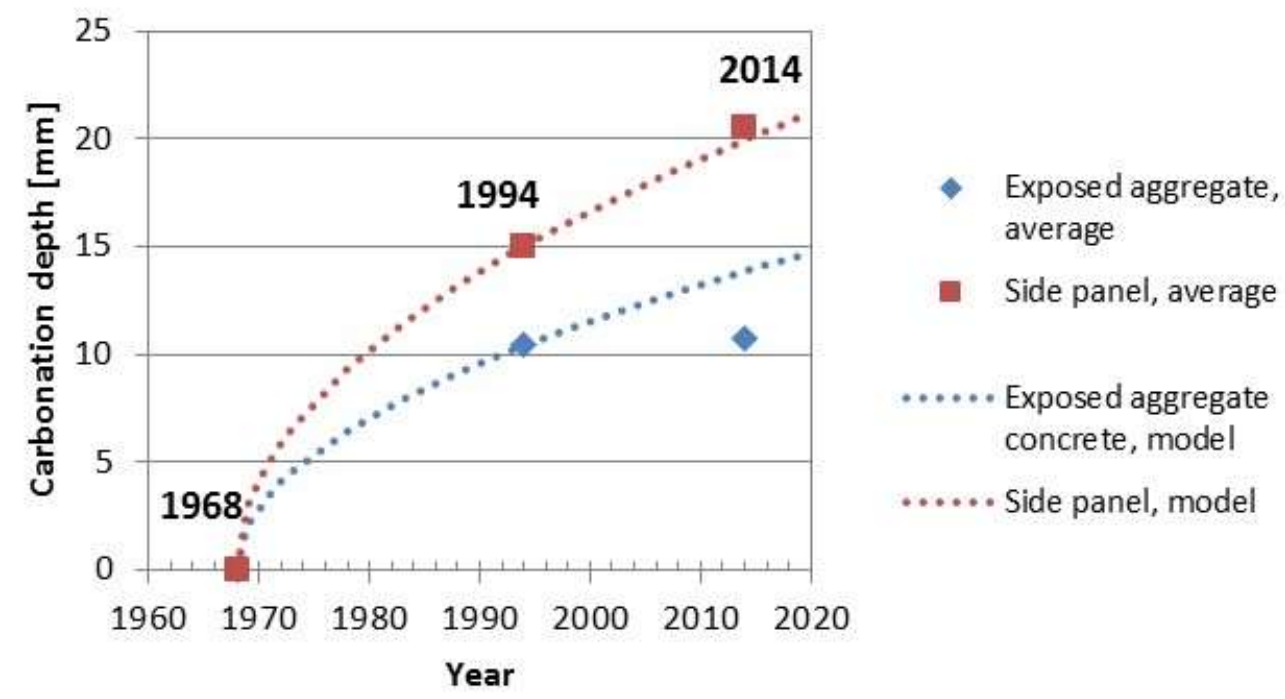

Figure 3 - Average carbonation of concrete in 1994 and 2014 and computational progress of carbonation based on the first condition investigation.

In balcony side panels the carbonation coefficient in 1994 was $2.94 \mathrm{~mm} / \mathrm{a}^{0.5}$ and in 20143.02 $\mathrm{mm} / \mathrm{a}^{0.5}$ (std. dev. 0.69). The side panels' carbonation coefficient was approximately same in both condition investigations and the difference is caused by inaccuracy in measurement of carbonation depth and inhomogeneity of concrete.

In sandwich panels in 1994 the carbonation coefficient was $2.04 \mathrm{~mm} / \mathrm{a}^{0.5}$ (std. dev. 0.53) and in 2014 it was $1.59 \mathrm{~mm} / \mathrm{a}^{0.5}$ (std. dev. 0.24) which is significantly lower. Lahdensivu [1] has analysed the carbonation of concrete facades and balconies under real outside environment in a study of 947 concrete buildings built between 1960 and 1996. The average carbonation coefficient for exposed aggregate concrete panels was $1.96 \mathrm{~mm} / \mathrm{a}^{0.5}$ in concrete panels made in $1960 \mathrm{~s}$ and1970s. Compared to this average carbonation coefficient of $2.04 \mathrm{~mm} / \mathrm{a}^{0.5}$ from 1994 made condition investigation, it gives an impression on very common concrete for that era. However, freeze-thaw damage was detected in exposed aggregate concrete as early as 1994. Freeze-thaw damage has caused small cracking to concrete surface and, therefore, diffusion of carbon dioxide into concrete pore structure is faster than in solid concrete. Therefore, the calculated carbonation coefficient does not illustrate the progress of carbonation deeper in the concrete.

In Figure 4 is presented different carbonation curves for sandwich panels to illustrate the progress of the carbonation. 


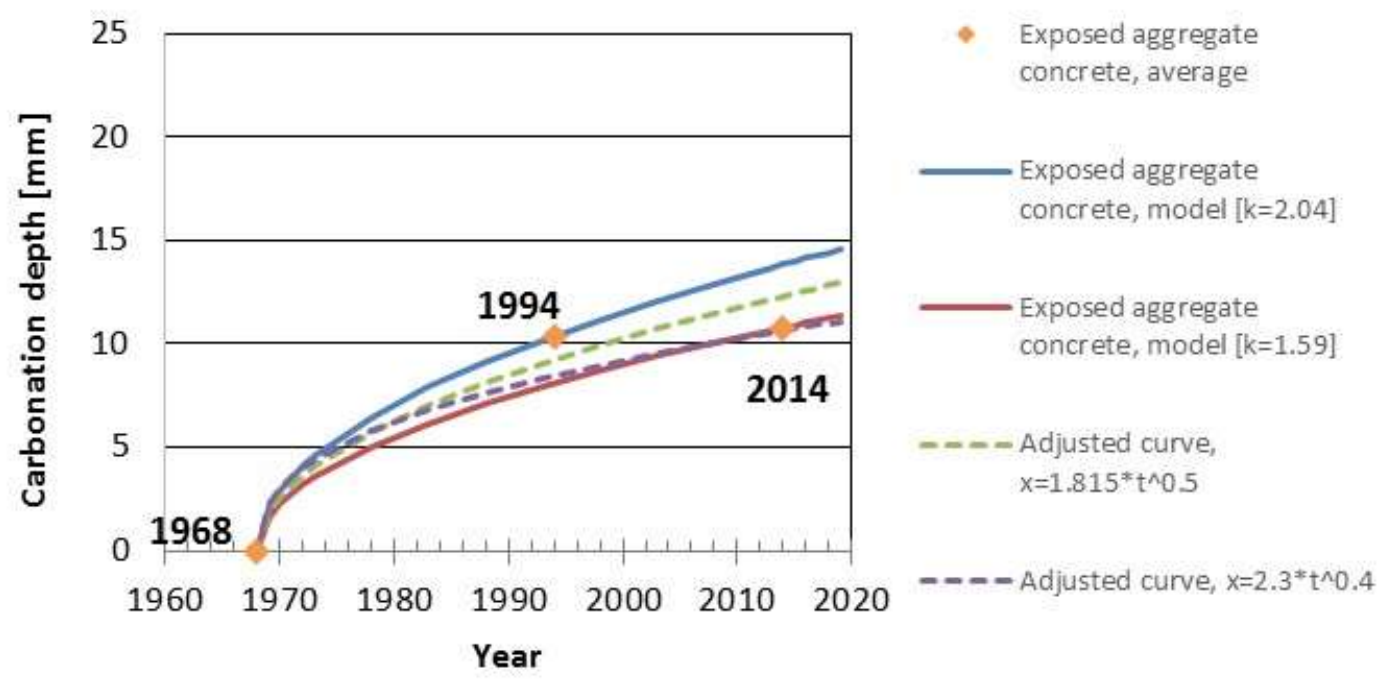

Figure 4 - Average carbonation of concrete in sandwich panels in 1994 and 2014 and computational progress of carbonation based on two different models.

In Figure 4 the progress of carbonation has been adjusted with square root model (Eq. (1)), too. Three different curves have been drawn: carbonation coefficient $\mathrm{k}=2.04$ (first condition investigation), $\mathrm{k}=1.59$ (second condition investigation) and $\mathrm{k}=1.815$ (average of both condition investigations). The fourth curve in the Figure is adjusted based on Eq. (3).

If Eq. (1) and the uppermost curve are used for freeze-thaw damaged concrete, it gives too pessimistic estimation on the condition of the reinforcement's state of corrosion. In 2014 it gives $4 \mathrm{~mm}$ deeper carbonation depth than it actually is. Therefore, more reinforcement will be exposed and repaired than actually needed. This could lead to too heavy repair, e.g. overcladding instead of patch repair.

If Eq. (1) is used in this case together with the curve based on the latter carbonation measurements $(\mathrm{k}=1.59)$ it gives a too positive estimation of what has happened in the early age of the façade. This may lead to the underestimation of the time that certain depth of the concrete has been carbonated. This may lead to underestimation of the corrosion propagation of rebars and the underestimation of rebar diameter loss or the need of patch repair.

The Eq. (1) together with the adjusted average curve work adequately in describing both early and later phases but any prediction made using this trend line will overestimate the further progression of carbonation.

Eq. (1) gives too pessimistic values for carbonation in freeze-thaw damaged concrete as can be seen in Figure 4. For freeze-thaw damaged concrete the adjusted curve follows Eq. (3):

$x=k t^{0.4}$

where,

$x=$ carbonation depth

$k=$ carbonation coefficient $\left[\mathrm{mm} \cdot \mathrm{a}^{-0,4}\right]$

$t=$ time [a]. 
In this case study several samples were taken from one building only. Samples were taken from exposed aggregate concrete sandwich panels and balcony side panels. Compared to the data collected from large number of buildings, the measured carbonation rates were very common, as well as the large deviation of carbonation rates.

In the most service life models of reinforced concrete structures the initiation phase is the most crucial, because according to models, service life of the structure will end when carbonation achieves the reinforcement for the first time. Initiation phase is usually modelled after simplified solution of Fick's second law. In solid concrete the progress of carbonation can be predicted reliably with usually used square root model. This model, however, gives too pessimistic predictions for concrete suffering from freeze-thaw damage.

Freeze-thaw damaged concrete (in this case exposed aggregate concrete) may alter the progression of carbonation from the conventional model. Carbonation is slowed down due to more moisture being able to penetrate the freeze-thaw cracked concrete and the concrete stays wet for longer time. The slowing down can be described by altering the time-exponent in the common square root relationship Eq. (3) instead of Eq. (1).

\section{REFERENCES}

1. Lahdensivu J: "Durability properties and actual deterioration of Finnish concrete facades and balconies". Tampere, Tampere University of Technology, Publication 1028, 2012, 117 p + app. 37 p.

2. Page C. L: "Basic Principles of Corrosion". In: Schiessl P (editor): Corrosion of Steel in Concrete, London, Chapman and Hall, 1988, pp. 3-21.

3. Schiessl P: "Corrosion of Steel in Concrete". London, Chapman and Hall, 1988, 101 p.

4. Liu Y \& Weyers R E: "Modelling the Time-to-Corrosion Cracking in Chloride Contaminated Reinforced Concrete Structures". ACI Materials Journal, Vol. 95, No. 6, 1998 , pp. $675-681$.

5. Tuutti K: "Corrosion of steel in concrete". Stockholm, Swedish Cement and Concrete Research Institute, CBI Research 4:82, 1982, 304 p.

6. Li C Q: "Reliability service life prediction of corrosion affected concrete structures". ASCE Journal of Structural Engineering, Vol. 130(10), 2004, pp. 1570-1577.

7. Concrete Association of Finland: "Concrete codes". Helsinki, The Concrete Association of Finland, BY 65, 2016, 164 p. (in Finnish)

8. Concrete Association of Finland: "Selection of concrete and service life design - guideline for construction designers". Helsinki, The Concrete Association of Finland, BY 68, 2016, 95 p. (in Finnish)

9. Pentti, M., Huopainen, J., Lahdensivu J., Mäkelä, K. "Condition investigation of concrete facades and balconies in Jakomäki”. Tampere University of Technology, Research report 274, 1994, 93 p. (in Finnish)

10. Parrott L J: "A review of carbonation in reinforced concrete". Cement and Concrete Association, Slough, UK, 1987, 42 p.

11. Huopainen J: "Carbonation of concrete facades - a field study". Tampere University of Technology, MSc thesis, 1997. (in Finnish)

12. Neves R, Branco F A \& de Brito J: "A method for the use of accelerated carbonation tests in durability design". Construction and Building Materials, Vol. 36, 2012, pp. 585-591. 
Nordic Concrete Research - Publ. No. NCR 60 - ISSUE 1 / 2019 - Article 1, pp. 1-12

13. fib Bulletin No. 34. "Model Code for Service Life Design". International Federation for Structural Concrete, Lausanne, 2006, 116 p.

14. Concrete Association of Finland: "Condition assessment manual of concrete facades and balconies". Helsinki, The Concrete Association of Finland, BY 42, 2013, 163 p. (in Finnish)

15. Lahdensivu J, Varjonen S, Pakkala T \& Köliö A: „Systematic condition assessment of concrete facades and balconies exposed to outdoor climate". International Journal of Sustainable Building Technology and Urban Development, Vol. 4:3, 2013, pp. 199-209.

16. Concrete Association of Finland: "Durability of concrete structures". Helsinki, The Concrete Association of Finland, BY 9, 1976, 44 p. (in Finnish) 